\title{
The Urgency of Guidelines for the Long-term Sustainability of Outer Space Activities for Indonesia
}

\author{
Yunita Permatasari \\ Lembaga Penerbangan dan Antariksa Nasional (LAPAN)
}

\begin{abstract}
The rapid increase in the use and exploration of outer space raises concerns about its sustainability in a sustainable manner. Countries seek multilateral solutions through the guidelines for the long-term sustainability of outer space activities (LTSOSA) which was adopted in June 2019 in the United Nations Committee on the Peaceful Uses of Outer Space (UNCOPUOS) forum. Indonesia as a country that organizes the use and exploration of outer space has an interest in ensuring the security of the implementation of outer space in a sustainable manner. Thus, it is necessary for the mapping of Indonesia's interest in implementing the LTSOSA guidelines. The interest mapping will illustrate the urgency of the LTSOSA guidelines for Indonesia's national security particularly outer space security. The analysis shows that the LTSOSA guidelines contain items related to outer space security which are of vital national importance to Indonesia. This article is expected to become input for Indonesia's attitude and position towards the implementation of the LTSOSA guidelines.
\end{abstract}

Keywords: Indonesia, long term sustainability of outer space activities, outer space security

Penggunaan dan eksplorasi antariksa yang semakin pesat menimbulkan kekhawatiran terhadap kelestariannya secara berkelanjutan. Negara-negara mencari solusi secara multilateral melalui pedoman kegiatan antariksa berkelanjutan jangka panjang atau dikenal guidelines for the long-term sustainability of outer outer space activities (LTSOSA) yang disahkan pada Juni 2019 dalam forum United Nations Committee on the Peaceful Uses of Outer Outer space (UNCOPUOS). Indonesia sebagai negara yang menyelenggarakan penggunaan dan eksplorasi antariksa berkepentingan untuk menjamin keamanan penyelenggaraan keantariksaannya secara berkelanjutan. Dengan demikian, perlu adanya pemetaan kepentingan Indonesia dalam mengimplementasikan guidelines LTSOSA. Pemetaan kepentingan akan menggambarkan mengenai urgensi guidelines LTSOSA bagi keamanan nasional Indonesia khususnya bidang keantariksaan. Tulisan ini menemukan bahwa guidelines LTSOSA memuat butir-butir terkait keamanan keantariksaan yang menjadi kepentingan nasional vital bagi Indonesia. Artikel ini diharapkan menjadi bahan masukan sikap dan posisi Indonesia terhadap implementasi guidelines LTSOSA.

Kata-kata kunci: Indonesia, keamanan keantariksaan, keberlanjutan kegiatan luar angkasa dalam jangka panjang 
The use and exploration of outer space activities are growing along with the benefits of human resources, science, and technology. Nowadays, outer space activities are not only carried out by governments or intergovernmental international organizations but also by the private sector. The increasing number of outer space actor is related to the increasing number of outer space vehicles which launch and orbit to Earth. It makes the outer space environment becomes denser, especially the near-earth orbit, with the condition of 19,000 satellites that orbiting to Earth (UNOOSA Secretariat 2016). But one thing that needs to be remembered is outer spacecraft are vulnerable to collisions with one another and disruption of satellite frequencies.

Furthermore, the security of the outer space environment is politically vulnerable because the number of countries engaging in outer space activities is increasing. It can be seen from their efforts to build a national outer space agency, national outer space law, and the outer space industry. Every country is competing in mastering outer space science and technology because it will affect not only to power bargaining but also improving the country's welfare. The race to be the master in science and technology of outer space has finally spurred countries to use nuclear energy sources in outer space vehicles and the creation of anti-satellites.

The situation of contemporary outer space activities becomes the arena of outer space power competition and the insecurity of the outer space environment occurs because it can't guarantee about free of outer space-based threats to the use and sustainability of outer space access, since the outer space power race is being the most serious threat to outer space security (Susilawati, 2011). Security dilemma can't be avoided, where other countries will move to develop weapons in outer space as a response if one country did it first. If this happens continuously, it can be denied that a battlefield would be formed in outer space.

United Nations Committee on Peaceful Uses of Outer Space (UNCOPUOS) was formed as one of the solutions to the mess. UNCOPUOS's scope is the issue of overcrowding and environmental safety in the agenda of the Scientific and Technical Subcommittee session since 2010. The final results of the discussion of this agenda are non-binding guidelines for countries and international intergovernmental organizations in the use and exploration of sustainable outer space activities in the long term (COPUOS 2016). These guidelines named LTSOSA guidelines which were finally agreed on overall and approved by the UNCOPUOS Committee and adopted as guidelines at the UN General Assembly session in June 2019 (COPUOS 2019). Indonesia has an interest in ensuring the implementation of sustainable outer space for present and future generations. Also, Indonesia also interested in ensuring that the dual use of outer space doesn't interfere with Indonesia's national security, together with Indonesia's efforts to improve technology and regulatory aspects of the administration of outer space further. This situation based on the accordance with article 2 of the Law of the Republic of Indonesia No.21 of 2013 concerning Outer space.

Based on the description above, the article is aiming to confirm the LTSOSA guidelines as an alternative solution to respond to national security threats. In particular, Indonesia's national security threats have increased, mainly outer space-based threats which are directly proportional to the increase in international outer space activities. Thus, this paper seeks to provide arguments for Indonesia in implementing the LTSOSA guidelines which are not merely due to external encouragement, but also because of internal needs. 


\section{The Research Gap between LTSOSA Guidelines: A Discussion about National Security}

Several studies have been conducted on the LTSOSA guidelines, including the origins of the LTSOSA initiative at UNCOPUOS, the development of an international compendium of LTSOSA guidelines, and maintaining LTSOSA: the creation of the regulatory framework to guide the APSCO and selected legal issues. In the first research entitled "The Origins of LTSOSA Initiative at UNCOPUOS" by Gerard Brachet in 2012, explained about the background of the emergence of the LTSOSA issue in UNCOPUOS (Brachet 2012). However, this research only focuses on the origin of the discussion of the LTSOSA guidelines in UNCOPUOS because there is no guarantee of long-term use of outer space accompanied by the ineffectiveness of UNCOPUOS efforts in the outer space debris mitigation guidelines so that the introduction of the LTSOSA concept is simultaneous discussion with PPWT and $\mathrm{ICoC}$, all three involved in a discussion of security regarding UNCOPUOS in outer space debris mitigation guidelines. In the second study, "The Development of an International Compendium of LTSOSA Guidelines" by Peter Martinez in 2018, explained the discussion in the LTSOSA working group as a multilateral initiative related to outer space safety considering input from the results of working groups on governmental groups 'experts' transparency and confidence-building measures (GGE TCBM) (Martinez 2018). In the third study, "Maintaining LTSOSA: The Creation of Regulatory Framework to Guide APSCO and Selected Legal Issues" by Yongliang Yan in 2019, explained that the LTSOSA guidelines contain aspects related to outer space law that APSCO should also develop (Yan 2019). Based on these studies, the authors find a research gap; the absence of a discussion of the LTSOSA guidelines for national security. Therefore, this study seeks to fill the void of academic literature regarding the urgency of LTSOSA guidelines for national security, especially in Indonesia.

This paper will be focusing on the content of the LTSOSA guidelines for the sustainability of Indonesia's outer space activities. The LTSOSA guidelines will easily be implemented if they show the benefits for the country. This idea is going hand in hand with international efforts in supporting sustainable outer space activities through the development of the benefits (Williamson 2012). The threat of overcrowding and insecurity of the outer space environment which tried to find the solution through the LTSOSA guideline is not necessarily effective. However, the presence of LTSOSA guidelines is one of the tangible steps in the efforts to maintain the safety of the outer space environment. For the outer space actor itself, especially developing countries in the outer space technology, can carry out outer space activities safely. Thus, the main issue of this paper is the urgency of the LTSOSA guidelines for Indonesia in terms of the security aspects of national outer space. To dissect the main problem as stated above, the question that is attempted to be answered through the writing of this article is what is Indonesia's interest in implementing the LTSOSA guidelines?

For answering the main questions above, authors use a realist perspective. The normative basis of realism is national security and the survival of the state as a national interest. Realism defined the concept of national security is a condition that's free from threats or the ability of a country to protect its nation-state from external environment attacks (Scheuerman 2009). Buzan (1987) added that national security is not only related to threats but also the country's vulnerability and their ability to protect national interests from all forms of interference. National security is the core of the survival of a country; thus, each country will fight for maintaining its national security. 
International law could be used as an effort for a country to intensify their power. In this case, the LTSOSA guidelines are instruments of international law despite its definition and implementation, it tends to be a soft law. Indonesia as a developing country has positioned international law as an instrument to increase its power and achieve its interests due to the limitations of its defense system. The advantage of advocacy, international law for developing and small countries is important as a potential pattern of state interaction in a better and fair international system in the dynamics of international politics.

Therefore, the contents of the LTSOSA guidelines will be identified as an instrument of increasing Indonesia's strength in maintaining national security. Basic requirements for maintaining national security include preventing all of the threats from state and non-state actors and the threat of natural disasters that can destroy a country (Nugroho 2013). Bearing in our mind, national security is the basis of maintaining the survival of the country through several instruments, in this case, it is focused through the instrument of outer space. National outer space security includes all of the matters relating to the ability to keep Indonesia's outer space secure from the threat and vulnerability of the outer space environment.

\section{Why Does Indonesia Need to Promote LTSOSA Guidelines?}

On 8 July 1976, Indonesia launched the first domestic satellite of Palapa-A1. Indonesia was the third country after the United States and Canada which developing satellite technology at that time (Susilawati 2011). Until now, Indonesia continues to improve the implementation of outer space from the scientific aspects of engineering and regulatory aspects. Indonesia is also active in international forums for outer space, both regionally such as APRSAF and globally such as UNCOPUOS.

Outer space security is one of the important orientations for Indonesia. This statement is reflected in Chapter VI of Law No. 21 of 2013, explained that Indonesia has an interest in ensuring the safe implementation of sustainable outer space. Indonesia has developed satellites independently, through the National Aeronautics and Outer space Agency (LAPAN) from LAPAN Tubsat, LAPAN A2 to LAPAN A3. Also, Indonesia through LAPAN developed a satellite launch rocket. Since Indonesia is using the outer space data so much, it would be important for Indonesia itself give concern to outer space security. Since Indonesia is using outer space data so much, it would be important for Indonesia to give concern to outer space security. The outer space security needs to be guaranteed because, as we know, Indonesia was trying to increase the capability of Indonesia's satellites. Moreover, the effort to increase the capability of the satellite was executed independently. The existence of these satellites in outer space has a vital function for Indonesia as in supervising border areas from above, for overseeing Indonesia's natural resources that have high potential and value, and for communication to connect between remote areas in Indonesia (Susilawati 2011). Another condition that leads Indonesia for having the concern to its outer space is the wide area of its sovereignty, 1/8 around Earth (Susilawati 2011). The huge area makes Indonesia vulnerable to falling objects. Indonesia's position crossed by the equator is the longest from 9812 ' BT to 129 20' BT. There's an advantage if a country orbiting satellites in the GSO, the satellite will be moving by with the rotation of Earth. This fact encourages many countries to compete for placing their satellites in the GSO. 
From the description above, Indonesian outer space security is important, because of those activities conducted, such as utilize outer space data, research and develop outer space science and technology. Related to national interests, outer space security is one of the common interests of all countries in the world, both developed and developing countries (Jusheng 2006). One such collaboration is to work together in creating guidelines for guaranteeing the implementation of sustainable outer space or LTSOSA guidelines; as one of the solutions.

\section{LTSOSA Guidelines: The Solution or Just Normative Guidelines?}

The discussion about LTSOSA was initiated in 2010, in the UNCOUOS framework. It's France who submitted a proposal regarding the discussion of the LTSOSA issue (COPUOS 2010). France's proposal is related to various issues that had a concern to countries, in essence, France proposed the long-term sustainability of outer space activities. The Long-term sustainability of outer space activities includes several issues related to the security of outer space activities for current and future generations. Aside from that, the proposal also talked about outer space vehicles, commercial satellite launch operators, increasing numbers of state and private entities, accidental collisions between Iridium 33 and Cosmos-2251 satellites on February 10, 2009. These issues need to be regulated to ensure outer space activities can last in the long run for the welfare of humanity. Thus, the long-term sustainability of outer space activities (LTSOSA) is a subject that addresses the issue of overcrowding and environmental safety through the discussion of the long-term sustainability of outer space activities.

From the previous paragraph, an important point that can be underlined related to the historical background of the LTSOSA guidelines is, France is the country that proposed the first discussion of this issue at UNCOPUOS. This issue arises because of the worrisome about the outer space environment with increasing outer space actors, outer space debris, and the existence of intentional satellite collisions. Furthermore, all countries supported the discussion and sought to develop LTSOSA guidelines led by G. Brachet from South Africa. At the LTSOSA guidelines, the document has been adopted and all countries are encouraged to implement it voluntarily. The LTSOSA guidelines were approved at the June 2018 of COPUOS session (COPUOS 2018). The guidelines are contained in the 62nd session of the COPUOS session (A / 74/20). In the report, the LTSOSA guidelines are contained in annex II p.50. These LTSOSA guidelines, although they have been adopted, are still open to revision following developments and implementation practices under COPUOS procedures.

The LTSOSA guidelines in the annex to the COPUOS A / 74/20 report contain strategies to ensure sustainable outer space activities. Including the approach in normative policy and regulation. This guideline is non-legally binding, but countries, which approved the guidelines, are encouraged to implement it consistently with the principles and norms of international law. Following the COPUOS report document, the LTSOSA guidelines contain 21 guideline items divided into four categories, including policy and regulatory framework for outer space activities; safety of outer space operations; international cooperation; capacity building; and awareness, as well as scientific and technical research and development. Based on the LTSOSA guidelines category, all points are needed in ensuring sustainable outer space activities. However, there is also a context in the LTSOSA guidelines that contains those who are also related to the 
implementation of the LTSOSA guidelines. These points in the LTSOSA guidelines must be considered and adjusted to the interests of Indonesia. Indonesia's interest in ensuring the implementation of sustainable outer space and accommodating the challenges and threats to national outer space security.

The LTSOSA guidelines relate to national security, especially national outer space security is found in three points. First, in para 13 regarding steps to build transparency and confidence (TCBM). Second, point B.8 related to the design and operation of outer space objects without regard to physical and operational characteristics. Third, point B.10 about observing the steps when using a laser beam that passes through outer space. The three points are classified based on the challenges and threats to Indonesia's outer space security, including: First, para 13 in the context of the LTSOSA guidelines especially in the definitions, objectives, and scope of the guidelines. They contain in this guideline is considered as recommendations in the form of a report from a group of government experts on steps to build transparency and confidence (TCBM) in outer space activities according to OOSA document A / 68/189. Second, article B.8 in the safety operating guidelines category. This article regulates the design and operation of outer space objects without considering physical and operational characteristics. There are three core points of this, the design of outer space objects that are easy to track, the development of manufacturing and operators under physical and operational characteristics, and small satellites that are difficult to track are still allowed especially for developing countries and emerging outer spacefaring countries. Third, article B.10 in the same category, regarding safety guidelines for outer space operations. This article regulates the observation of steps when using a laser beam that passes through outer space. This explains that it is necessary to analyze the possibility of accidental illumination that passes through outer space objects.

From the description above, an important point can be underlined between 1 para and 2 articles of the LTSOSA guidelines, namely the para and articles have been classified based on the concept of national security, especially national outer space security. Based on this concept, national outer space security is a guarantee for Indonesia's freedom from threats and challenges of military outer space activities both from State and non-military actors. These three LTSOSA guideline points, substantially, regulate three things as follows: a) State actors regarding transparent outer space activities so as to avoid security dilemmas (para 13), b) state and non-state actors regarding outer space objects (article B.8), c) infrastructure security on Earth and outer space from laser light (article B.10). These required international regulations because Indonesia haven't developed outer space technology that can secure outer space activities and infrastructure in its orbit. It included the statement of outer space objects that can't be traced and the use of laser beams.

\section{Indonesia's Steps Toward Securing Outer Space}

These LTSOSA Guidelines can be one of Indonesia's steps in manifesting outer space security. Given the dual use of dual technology for both civilian and military impact on international peace, safety and security. Indonesia has ratified and followed the principles of the international outer space treaty which includes: The Treaty on Principles Governing the Activities of States in the Exploration and Use of Outer Space including the Moon and Other Celestial Bodies 1967 (Outer space Treaty); Agreement 
on the Rescue of Astronauts, the Return of Astronauts and the Return of Object Launched into Outer Space 1968 (Astronauts Agreement), Convention on International Liability for Damage Caused by Outer space Objects 1972 (Liability Convention), and Convention on Registration of Objects Launched into Outer Space 1976 (Registration Convention. Meanwhile, Agreement Governing the Activities of States on the Moon and Other Celestial Bodies 1984 (Moon Agreement) it has not been ratified yet because it is not related to Indonesia's outer space capabilities at that time. Also, Indonesia has national outer space regulations with Law of the Republic of Indonesia on No. 21 of 2013 concerning outer space.

In organizing outer space, it couldn't be avoiding the challenges and threats. The administration of outer space is the right of all countries following the 1967 outer space treaty. Thus, the challenges and threats of organizing outer space are the responsibility of all countries without exception. There are two categories of challenges to outer space security (Jusheng 2006). First, dense orbits, lack of channels for frequency distribution, increased outer space debris originating from outer space objects, the increasing involvement of state and non-state actors in outer space activities and increasing development of outer space activities by humans. Second, the threat of outer space weaponization and the arms race. Indonesia has a large risk of having fall objects from outer space, since the huge territory (Susilawati 2011). Indonesia positioned on $13 \%$ of GSO lines, such a large area for the big risk itself. Those facts are the challenge for the Indonesian outer space security. Thus, to assure the security of national outer space, Indonesia must counter the challenge. One of the ways is by working together with other countries in various forms of international forums.

Also, outer space security challenges arise from the development of the international situation. In the current era of globalization, every country both developed and developing countries have a dependency on outer space assets, although the magnitude of this dependence varies (Susilawati 2011). This globalization has an impact on the increasing number of state and non-state international outer space actors, which are in line with the increasing development of human outer space activities based on Pan Jusheng's category as a national security challenge. Indonesia as an emerging outer spacefaring nation must not only be a spectator but also an active actor. Indonesia must behave under the principles of the international outer space treaty, the Indonesian outer space law, and Indonesia's national interests. The principle explained that the use and exploration of outer space are only for peaceful purposes so that Indonesia has an interest in ensuring that the implementation of international outer space runs according to these principles. Indonesia's response to this threat is by actively participating in international fora discussions in preventing the misuse of outer space and its technology. Likewise, following the development of the Governmental Group of Experts on Transparency and Confidence Building Measures, the International Code of Conduct of Outer Space was a great example.

From the explanation above, it can be mapped that Indonesia's outer space security challenges include: the fall of outer space debris, dense orbits, and saturated frequencies, especially in the GSO, and the increase in actors and outer space activities. While the threats to the security of Indonesian outer space are weaponry and the outer space arms race. Indonesia as a developing country and does not have the ability yet in mastering technology, technically there is not much that can be done by Indonesia to play a role in keeping outer space safe. As for Indonesia itself, Indonesia's efforts or outside contribution that can be done to keep outer space safe is through active 
The Urgency of Guidelines for the Long-term Sustainability of

Outer Space Activities for Indonesia

participation in every international discussion forum (Susilawati 2011).

\section{Discussing the Issues: LTSOSA and the Expected Result for the National Security}

The inability of individual countries to overcome the challenges and threats to national outer space security is what makes the importance of the results of the UNCOPUOS discussion on this issue. This is expected to bring up guidelines, even though the guidelines are non-legally binding but it is expected that all countries implement it voluntarily following the principles and norms of international law. Through the LTSOSA guidelines, countries receive guidance on safe and sustainable use and exploration of outer space. Countries can also use the LTSOSA guidelines for the basis of overseeing or criticizing the administration of other countries' outer space if they are deviating from international outer space law. Indonesia as an emerging nation outer space that hasn't provide high capabilities in the field of outer space, can use these LTSOSA guidelines in securing the implementation of outer space. So, Indonesia's active role in implementing LTSOSA guidelines becomes important. But still, Indonesia must ensure the implementation of the LTSOSA guidelines is in line with Indonesia's national interests.

In the current LTSOSA guidelines (A / 74/20), in particular, the three points of the LTSOSA guidelines relating to national outer space security need to be considered to Indonesia's national interests, specifically the interests of Indonesian outer space. Indonesia must take a position on this guideline, at least firmly believe in approving or rejecting it. National outer space security is a strategic thing that must be fought for world competition to achieve it, Indonesia can use these global LTSOSA guidelines. Following Nuechterlein's opinion (Nuechterlin 1991), national interests have two characteristics: first, a set of state objectives that are fought for in world competition and not domestic interests, second, a strategic interest with a focus on the military and the economy.

Indonesia, according to the white paper of the Ministry of Defense selects three tiers of national interest; (a) absolute: the upholding of the Republic of Indonesia; (b) vital: sustainability of national development; (c) main: world peace and regional stability. Based on this level, the interests of national outer space are included as vital interests. Outer space technology is an inseparable part of human life without realizing it. With the spin off and spin in, outer space technology enters human life, such as banking technology, communication technology, health radiography technology, and others. Indonesia as the largest archipelago in the world needs outer space technology in its national development. The three points of the LTSOSA guidelines are based on the consideration that the three represent the highest increase in threats due to the growing development of outer space actors, which will be seen based on aspects of national security that are limited by looking at threats and vulnerabilities, as explained by Buzan (1987).

The 13 points of the regulation explain the transparency of outer space activities. Transparency is needed so that one country not threatened by the increase of the capacity of other countries or to minimize security dilemmas between countries. Through transparency, it will ensure the peaceful use of outer space and for the 
benefit of all people. Transparency is the main thing in development so that it can run sustainably because of the vulnerability of abuse of power outer spacefaring countries. Therefore, Indonesia needs to encourage the implementation of transparency in outer space activities.

Article B.8 regarding outer space objects, natural and artificial outer space objects are important to track so they can be controlled. In normal conditions, there is a threat of a collision in orbit, especially with the addition of the number of artificial outer space objects currently growing rapidly, the threat of collision is higher. Article B.8 regulates the operation and design of outer space objects. Outer space objects are arranged to be easy to track. However, the use of outer space objects, especially small satellites tends to difficult for tracing by. But it can't be ignored, it still needed for developing countries so there are exceptions to be allowed by following the principles of the LTSOSA guidelines. Indonesia as one of the developing countries whose institution has orbited three small satellites, so the implementation of this item is very much related to the capability of Indonesia's current satellite development.

Article B.10 concerning the use of laser light. The laser beam that has been used by China and India in anti-satellite systems (ASAT) poses a threat. These usages can't only be weaponry in outer space but also have an impact on the outer space environment. The object of the laser shooting becomes outer space junk and other outer space objects become vulnerable to the impact of the junk. Also, other outer space objects that are passed are threatened by the laser beam illumination. Therefore, the regulation of the use of laser light is very necessary because the threat is matter directly proportional to the ability of today's outer space technology, which is increasingly sophisticated with the increase in outer space actors both state and private as well as new national outer space laws. Indonesia which has not reached the ability to use laser light yet needs to encourage the implementation of this item to protect its outer space objects from the effects of using laser light.

According to Buzan, theoretically, national security is the ability of the state to achieve national interests everywhere, which is closely related to threats and vulnerability. According to BAPPENAS (2010), national security is an embodiment of one of the objectives of the state. From the description before, it can be seen that the main element of national security is freedom from all forms of threats and vulnerabilities or challenges in the goals of the State in this case which originate from outer space activities. The 13 points regulate the threat and vulnerability of abuse of outer space activities. Indonesia must take a profitable step by supporting the 13 points which contain measures to build transparency and confidence. Article B.8 regulates the threat of outer space objects that cannot be traced, it governs the design and operation of outer space objects. Indonesia must adopt a favorable policy by encouraging the implementation of this item because the interests of Indonesia as a developing country are guaranteed at this point. Such as allowing the use of outer space objects, in this case, small satellites that are difficult to track according to the principle of LTSOSA. Given the current technology in Indonesia has orbited three small satellites that are still actively operating. Article B.10 essentially regulates the use of laser light, the contents of which encourage the calculation of the possibility of accidental illumination from the use of laser light that passes through outer space. The use of laser light is a form of sophistication of outer space technology but it could become a threat because it gives the effect of adding outer space junk from objects destroyed by laser light. Then, it also raises the vulnerability of laser beam illumination on other outer space objects. 
Therefore, Indonesia has an interest in the Indonesian outer space object without the impact of the use of laser light.

Indonesia is a country that is classified as still far away in outer space and technology to overcome the above mentioned individually. Thus, inevitably international cooperation is the answer. The existence of LTSOSA guidelines becomes a quite effective choice. These guidelines are non-binding and under the United Nations framework, which means that they are in harmony with the spirit of Indonesia's free and active foreign policy. Then these guidelines can be one way to guarantee the freedom of Indonesia from the threat of saturation of the outer space environment (orbit density and outer space debris) and the challenges of using laser light on outer space objects.

Although according to Ratner, international law has two challenges in its implementation, namely how to make it a guideline that is followed by the state and how to make it strong in the absence of sovereign authority or supranational mechanisms (Art \& Jervis 2007). So, the key to running effective international law is who voluntarily wants to recognize and comply with international law. The state as a rational actor who always pursues interests will recognize international law that suits his interests or benefits him. If it is not following its interests or disadvantages the state will not admit it let alone obey it. Plus, the absence of a force that can impose international law makes the country free to behave or not consider the existence of international law. Therefore, Indonesia needs to encourage the practice of LTSOSA guidelines to be able to remain as an international law that is obeyed by all countries.

This is under the mandate of Law No. 21 of 2013 concerning outer space makes the administration of outer space the responsibility of the government. So, the security of national outer space including the challenges and threats facing Indonesia today and the importance of Indonesian outer space is one of Indonesia's national interests. The national interest is the main aspect that must be achieved by each country to continue to exist or survive with the main attention on high politics issues such as security through military power instruments (Susilawati 2011). Thus, the LTSOSA guidelines relating to guaranteeing the security of the implementation of sustainable outer space are Indonesia's national interests that must be achieved.

\section{Conclusion}

The current outer space environment faces challenges and threats of outer space activities including increasing state and non-state actors in outer space activities, outer space objects that are difficult to trace, and the use of laser beams. Indonesia as a country carrying out outer space activities classified as still, a developing country needs advocacy in maintaining the security of national outer space. The adoption of the LTSOSA guidelines can be one of Indonesia's instruments in increasing its strength. The LTSOSA Guidelines regulate these matters specifically in three points, namely para 13, item B.8, and item B.10. Therefore, Indonesia should carry out best practices in its implementation and encourage countries to jointly practice it internationally. 


\section{References}

\section{Book and Book Chapter}

Art, R., \& Robert Jervis. 2007. International Politics Enduring Concepts and Contemporary Issues (Eight Edit). New York: Pearson Education Inc.

BAPPENAS. 2010, Memperkuat Sinergi Antar Bidang Pembangunan, Buku II, Kementerian Perencana Pembangunan/Badan Perencana Pembangunan Nasional Nasional. Jakarta.

Buzan, Barry. 1987. An Introduction to Strategic Studies: Military Technology and International Relations. London: Macmillan Press ltd.

Nuechterlin, D.E., 1991. America recommitted: United States national interests in a restructured world. Kentucky: University Press of Kentucky.

Nugroho, Riant. 2013. National Security Policy: Sebuah Pengantar. Jakarta: Pustaka Pelajar.

Scheuerman, W. E. 2009. Hans Morgenthau: realism and beyond. Canada: Polity Press.

Susilawati, Euis. 2011. "Analisis Upaya Internasional Dan Kepentingan Indonesia Dalam Mempertahankan Keamanan Antariksa” in Kajian Kebijakan dan Informasi Kedirgantaraan, Jakarta: Massama Publishing.

\section{Journal and Online Journal}

Brachet, Gerard. 2012. "The origins of the 'Long-term Sustainability of Outer Space Activities' initiative at UN COPUOS”, Outer space Policy, (28): 161-165.

Martinez, Peter. 2018. "Development of an international compendium of guidelines for the long-term sustainability of outer space activities." Space Policy 43, 13-17.

Williamson, Ray A. 2012. "Assuring the sustainability of space activities." Space Policy 28 (3): 154-160.

Yan, Yongliang. 2019. "Maintaining Long-Term Sustainability of Outer Space Activities: Creation of Regulatory Framework to Guide the Asia-Pacific Space Cooperation Organization and Selected Legal Issues" Space Policy 47: 51-62.

\section{Online Article}

UNOOSA Secretariat. 2016. "Outer Space Debris" [online] http://www.unoosa.org/ oosa/en/ourwork/topics/outer space-debris.html, [accessed at 14 April 2016] 


\section{Others}

COPUOS. 2010, "Long Term Sustainability of Outer Outer space Activities" Working Paper Submitted by France, Scientific and Technical Subcommittee Fortyseventh session, 8 - 19 Pebruari 2016, A/AC.105/C.1/L.303, Vienna, Austria.

COPUOS. 2016. "Report of the Committee on the Peaceful Uses of Outer Space" COPUOS Fifty-ninth session, 8 - 17 Juni 2016, A/71/20, Vienna, Austria, p. 24.

COPUOS. 2018. "Report of the Committee on the Peaceful Uses of Outer Space" COPUOS Sixty-first session, 20 - 29 Juni 2018, A/73/20, Vienna, Austria, p. 27.

COPUOS. 2019. "Report of the Committee on the Peaceful Uses of Outer Space" COPUOS Sixty-second session, 12 - 21 Juni 2019, A/74/20, Vienna, Austria, p. 50.

Jusheng, Pan, 2006. "Addressing the outer space security issue: Building the Architecture for Sustainable Outer space Security" Conference Report March, United Nations. 